\title{
Coastal Restoration Based on Institutional Approach: A Case Study in the City of Probolinggo, East Java Province, Indonesia
}

\author{
Haji Rudianto \\ Faculty of Fishery and Marine Science, Brawijaya University
}

\begin{abstract}
The coastal area in Indonesia is currently experiencing a very heavy pressure, whether caused by human activities, or caused by natural processes. Damage to coastal ecosystems like mangroves, coral reefs, sea grass beds, estuaries and the region has reached at an alarming rate. It is estimated that more than 41 percent of the coastal area in Indonesia is experiencing environmental degradation. This leads to the coastal region can no longer support the region's ecological system. Associated with more severe coastal damage, it is necessary efforts to save the coast through the people residing in coastal areas as a subject of coastal development. In this regard, more comprehensive studies are needed to determine the institutional aspects as an effective solution for dealing with coastal restoration. The aim of this research is to handle of coastal environmental damage by coastal restoration based on institutional aspect, and to formulate institutional models in accordance with local wisdom. Therefore, it is needed a statistical approach with assumption that there is relationship between restoration of mangrove with institutional aspect. Partial Least Square (PLS) is used to examine such relationship. To analyse priority of institutional strategy, it is used SWOT analysis. The result of this research is that to overcome the damage of mangroves, it is necessary to formulate activities synergy among local government, private and local people. Therefore, Co-management approach is needed to strengthen mangrove Community Working Group. (CWS).
\end{abstract}

Keywords: coastal restoration, Partial Least Square, Strength Weakness Opportunity and Threats, mangrove community working group.

\section{INTRODUCTION}

The coastal area in Indonesia is currently experiencing environmental degradation due to irrational utilization rates without regard to sustainability. Ecological losses suffer is caused mainly by human activities. This problem is mainly concerns the trade off coastal resource use, for example between economic interests and the preservation of ecological functions (Fauzi, 2010). Coastal ecosystems degradation should be solved with more integrated and more comprehensive way. The relationship among ecosystems in coastal area is taking place in certain one unit of space. Therefore, among ecosystems has a mutual relationship and interdependence. According to Rudianto (2014) to deal with coastal damage, it is needed integrated manner with taking into account mangrove restoration is the first priority. Then the coral reefs and further the third priority is sea grass restoration. In order to be successfully to restore coastal area, it is needed to be supported by institution aspects. Wibowo (2009) mentioned that to realize integrated between government agencies with private and local people through the process of institutional based management. In its implementation the Institution that should be effective and efficient must have authority. In order to get authority, institution should have attribution and delegation. Attribution is the formation of a certain authority and administration to specific organs. While, delegates is defined as the delegation of authority by government officials to the other party and the authority are the responsibility of the other part. 
Coastal damage problem is not only how to do the restoration, but the capability and institutional capacity to carry out the restoration. The Failure of coastal restoration comes to handling damage technically regardless of the institutional aspects.

Based on the above reasoning, the restoration is done by rehabilitating of coastal mangroves as a top priority by strengthening community institutions as the main prerequisite of success of coastal restoration. Based on these ideas, the study was conducted in the district of Mayangan in Probolinggo. The argument is that such region is an area of mangrove restoration in urban areas with very high levels of damage vulnerability, because it is considering population growth and demand of land for various needs.

There are three objectives of this research that should be achieved. Firstly, it deals with damage of coastal environment based on the technical and institutional aspects. Secondly, it formulates institutional models in accordance with local wisdom. Thirdly, it describes the model in the form of coping strategies based on institutional mangrove restoration.

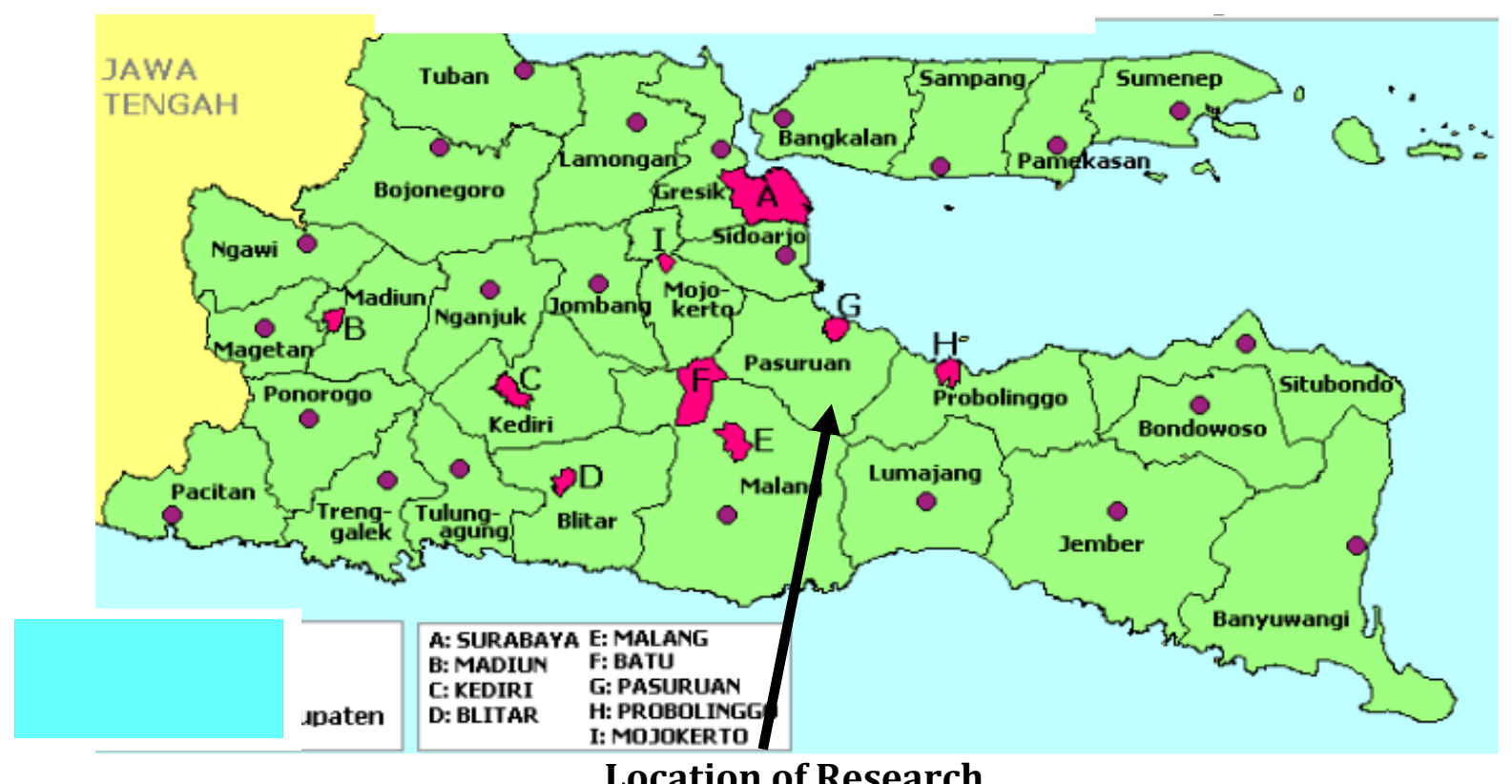

Fig 1. Map of Mangunharjo Village coastal area in Probolinggo, East Java, Indonesia

Mangunharjo village is located on the coastal areas along one kilometre of Probolinggo city shorelines. It has an area of 19.34 ha of mangrove forests with a height of land approximately four meters above sea level. (Wiyono, 2009). Condition of mangrove forest is the result of the restoration of mangrove forests conducted by Probolinggo government since the 1990s. People who are involved in restoring mangrove forest called Community Working Group (CWG) named Arum Jaya. CWG played in active role to restore mangrove in 2008 with a land area of 8 hectares.

Table 1: Sample location for Mangrove observations

\begin{tabular}{|c|c|c|c|c|}
\hline No & Region & Village & Types of Research & Sample size \\
\hline 1. & Probolinggo City & Mangunhardjo & Interview & 30 respondents \\
& & $\begin{array}{c}\text { Measurement of } \\
\text { Mangrove condition by } \\
\text { using sampling plot }\end{array}$ & $\begin{array}{c}5 \text { stations in } \\
\text { coastal area }\end{array}$ \\
\hline
\end{tabular}




\section{MATERIALS AND METHODS}

This research is focus on aspects of coastal biophysical environment to determine whether Mangunhardjo of coastal habitats is suitable for mangrove growth. It is also examine mangrove land suitability and it is also needed institutional analysis as the key to success for mangrove restoration including preparing model and treatment strategies.

Measurement of water quality parameters included: temperature, dissolved oxygen (DO), acidity $(\mathrm{pH})$, salinity, tides, substrate texture and organic $\mathrm{C}$. Whereas, to determine the condition of mangrove needs measurement of mangrove density, environmental carrying capacity and mangrove species dominance.

Table 2: Measurement of mangrove condition and water quality parameter

\begin{tabular}{|c|c|c|c|c|c|}
\hline Parameter & St1 & St2 & St3 & St4 & St5 \\
\hline Tree level & RM & RM $\quad \mathrm{AB}$ & RM $A B$ & RM $\quad \mathrm{AB}$ & $\mathrm{AB}$ \\
\hline - $\mathrm{Di}$ & 700 & $767 \quad 433$ & $700 \quad 300$ & $834 \quad 700$ & 600 \\
\hline & 1 & 1 & 11 & 11 & 1 \\
\hline - $\mathrm{Fi}$ & 0,1 & $0,3 \quad 0,4$ & $0,2 \quad 0,6$ & $0,3 \quad 0,7$ & 0,7 \\
\hline - $\quad C i$ & 300 & $155 \quad 144$ & 155144 & 174125 & 300 \\
\hline s & 1100 & $600 \quad 300$ & 1300900 & $900 \quad 1700$ & 1100 \\
\hline - INP & & $1 \quad 0,7$ & 11 & 11 & 1 \\
\hline Belta stage & 0,1 & $0,3 \quad 0,4$ & $0,8 \quad 0,8$ & $0,9 \quad 0,6$ & 0,3 \\
\hline - Di & 300 & $167 \quad 131$ & 167132 & 130169 & 300 \\
\hline $\mathrm{Fi}$ & 3333 & 20002000 & 2000100 & 10002667 & 1667 \\
\hline FI & & 11 & $0,7 \quad 0,7$ & 11 & 1 \\
\hline - $\mathrm{Ci}$ & 0,9 & $0,6 \quad 0,4$ & $0,2 \quad 0,3$ & $0,1 \quad 0,25$ & 0,5 \\
\hline IND & 300 & $160 \quad 140$ & 153146 & $130 \quad 169$ & 300 \\
\hline - IIVP & 30,5 & 29,4 & 29,5 & 28,9 & 30,2 \\
\hline Seedling stage & & 6,7 & 6,3 & 6,8 & 6 \\
\hline - $\mathrm{Di}$ & & 7,8 & 7,7 & 8,03 & 8 \\
\hline $\mathrm{\Gamma i}$ & 29,7 & 31,3 & 31,5 & 30,7 & 31,9 \\
\hline - $\mathrm{Fi}$ & Semi & Semi diurnal & Semi & Semi diurnal & Semi \\
\hline - $\quad \mathrm{Ci}$ & Sandy & Sandy Loam & Clay & & Sandy \\
\hline - INP & Loam & & & & loam \\
\hline Temperature & & & & & \\
\hline & & & & & \\
\hline $\mathrm{pH}$ & & & & & \\
\hline Salinity & & & & & \\
\hline Tides & & & & & \\
\hline $\begin{array}{l}\text { substrate texture and } \\
\text { organic C }\end{array}$ & & & & & \\
\hline
\end{tabular}

Source: Sri Rahayu (2014)

\section{Remarks:}

St: Station

INP: Important Value Index Fi: Frequency Type AB: Avecenia Alba

Di: density type RM : Rhizaphora Mucronata

Ci : Relative Closure Type Semi-Diurnal tides occur twice 
In order to analyse local institutional capacity called arum jaya as key to success to restore coastal damage, it needs latent variable consisting of the role of local government $(\mathrm{X})$, the role of CWS (Y1), the role of private (Y2) and effort to mangrove restoration (Y3).

Table 3. Validity and Reliability Testing of Latent Variables

\begin{tabular}{|c|c|c|}
\hline Variable & AVE & $\begin{array}{c}\text { Composite } \\
\text { Reliability }\end{array}$ \\
\hline X (Role of government) & 0.717 & 0.910 \\
\hline Y1 (Role of CWS) & 0.686 & 0.897 \\
\hline Y2 (Role of private) & 0.714 & 0.831 \\
\hline Y3 (Restoration of Mangrove) & 0.543 & 0.781 \\
\hline
\end{tabular}

\section{AVE: Average variance extraction}

Based on table 3 above, the convergent validity outer model has met requirements. whereas, the value of composite reliability in each variables is more than 0.6 , so it conclude that indicators of latent variable constituent has validity and internal consistency was good.

After testing validity of latent variables, it is prepared structural model conceptual image below and it can be explained that the conceptual model can be divided into three models based endogen variables, namely: Model 1, which is a model that describes the direct influence of the Role of Government (X) on the Role CWS (Y1).Model 2, which is a model that describes the direct influence of the Role of Government (X) on the Role of Private (Y2). Model 3, which is a model that describes the direct influence of the Role of Government (X), Role CWS (Y1) and Private Roles (Y2) of the Restoration of Mangrove (Y3).

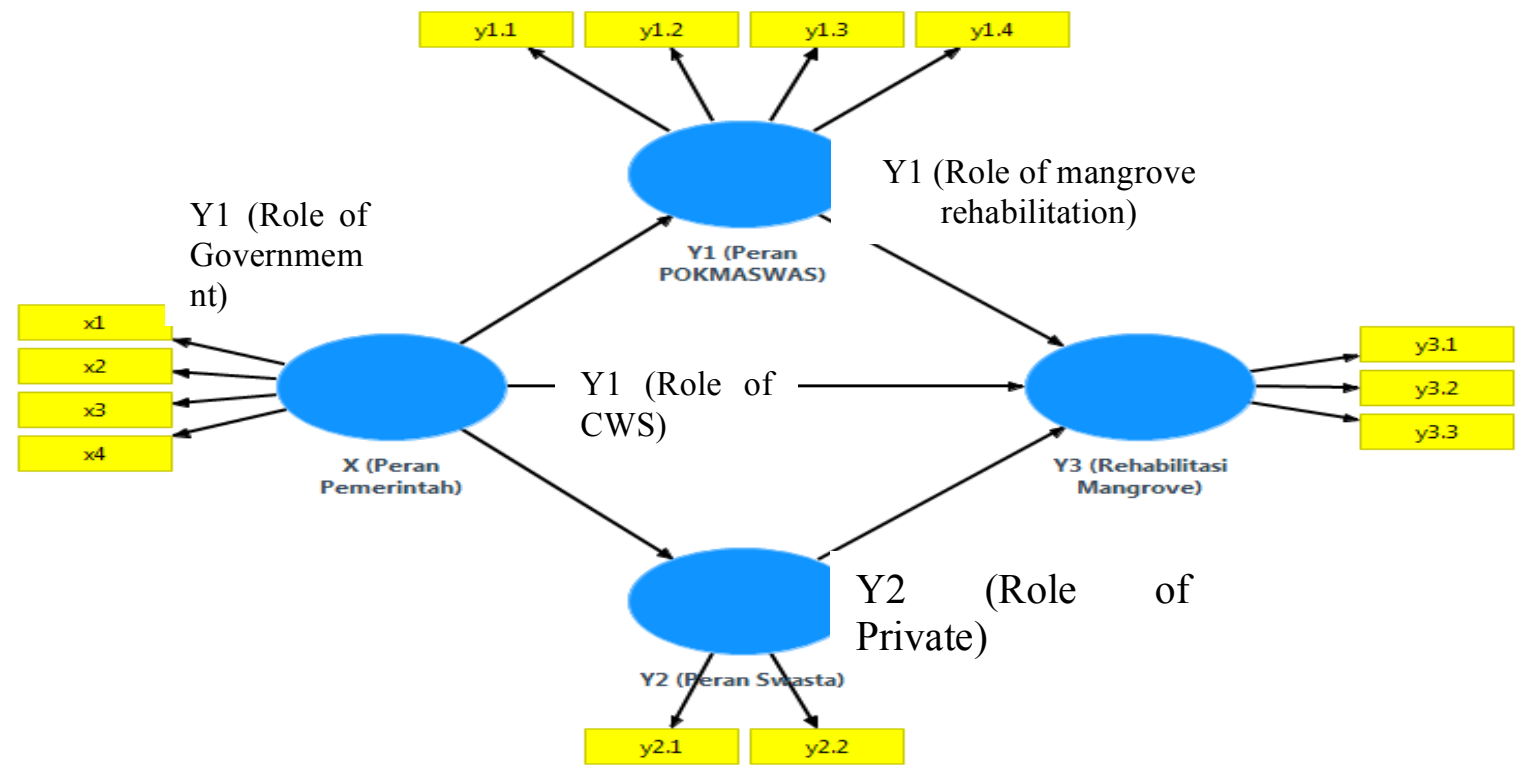

Figure 2: Structural Conceptual Model

CWS Role variable (Y1), it can be explained that all of the items making up the variable of CWS role (Y1) has a p-value less than 0.05 . Thus, it can be said that all indicators are significant. Public Awareness Indicators (y1.2) has a value of outer loading greatest. This indicates that the greatest contribution to the variable of CWS role (Y1) is measured by indicators Awareness (y1.2) 
Private Role variable (Y2), it can be explained that all of the items making up the variable Private Role (Y2) has had a p-value less than 0.05. Thus, it can be said that all indicators are significant .Indicator of personnel (y2.2) has a value of outer loading greatest. This indicates that the greatest contribution to the Private Role variable (Y2) is measured by indicators of Personnel (y2.2).

Mangrove Restoration variables (Y3), it can be explained that all the variables making up the indicator of Mangrove forest restoration (Y3) has had a p-value less than 0.05 . Thus, it can be said that all indicators are significant. Compliance Indicators for growth area mangrove (y1.3) has the greatest outer loading. This suggests that the suitability Land for growth of mangrove (y1.3) has the most contribution to the mangrove forest restoration variables (Y3) than other indicators.

Table 4: Direct Impact Testing Results Inner Model

\begin{tabular}{|l|l|c|c|c|}
\hline \multicolumn{1}{|c|}{ Exogen Variabel } & \multicolumn{1}{|c|}{ Endogen Variable } & $\begin{array}{c}\text { Coefficients } \\
\text { Path }\end{array}$ & $\begin{array}{c}\text { T- } \\
\text { Statistic }\end{array}$ & $\begin{array}{c}\text { p- } \\
\text { value }\end{array}$ \\
\hline Government role (X) & CWS role (Y1) & 0.548 & 3.267 & $0.001^{*}$ \\
\hline Government role (X) & Private role (Y2) & 0.304 & 2.254 & $0.025^{*}$ \\
\hline Government role (X) & \multirow{2}{*}{\begin{tabular}{l} 
Mangrove restoration \\
\cline { 1 - 5 } CWS role (Y1)
\end{tabular}} & 0.191 & 1.439 & $0.151^{\text {ns }}$ \\
\cline { 1 - 5 } Private role (Y2) & (Y3) & 0.424 & 3.179 & $0.002^{*}$ \\
\cline { 3 - 5 } & & 0.439 & 3.188 & $0.002^{*}$ \\
\hline
\end{tabular}

\section{Remarks :}

* : significant at the level of errors 5

\section{ns: not significant}

The results of hypothesis testing pathways direct influence can be seen in the following image path diagram.

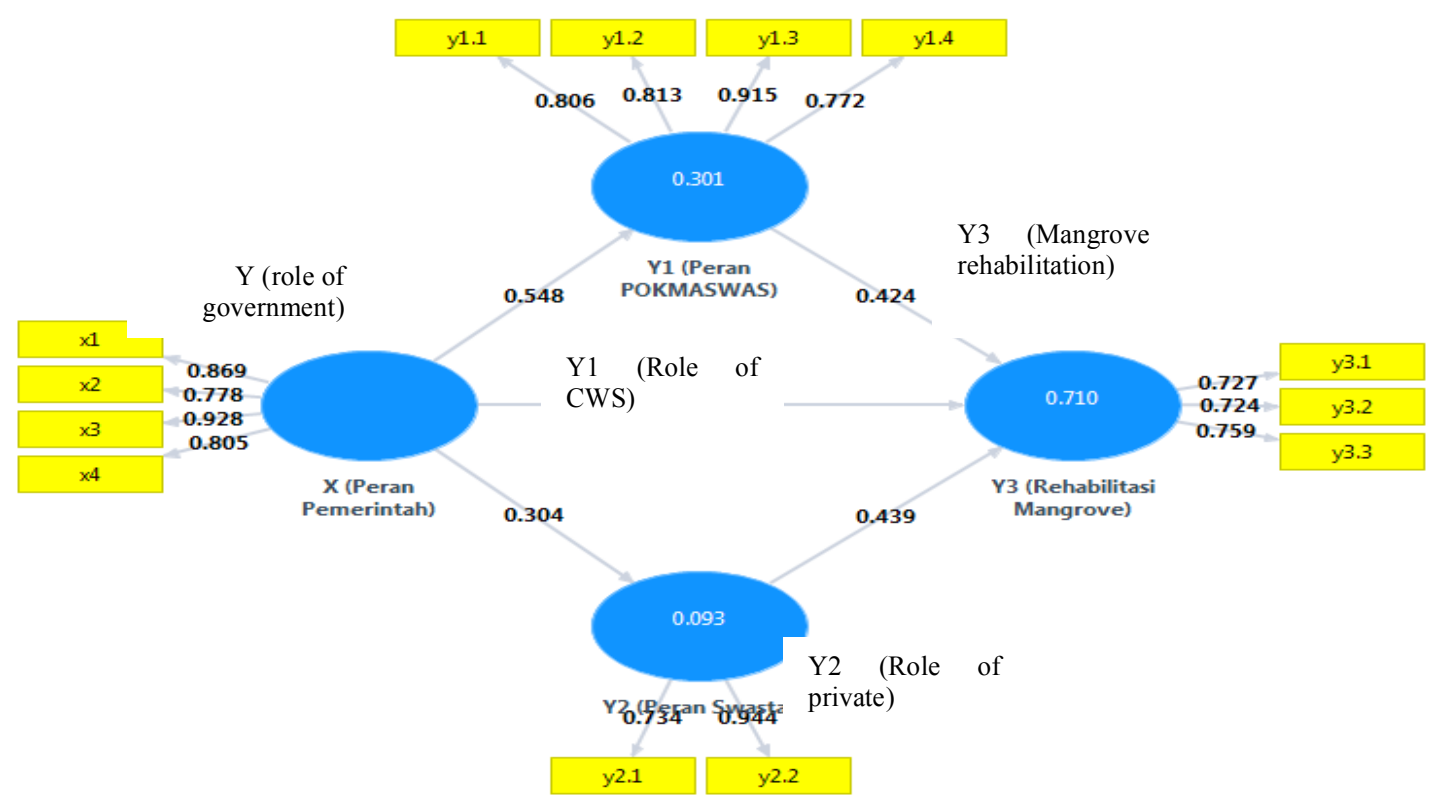

Figure 3: Hypothesis Testing Results of Line Diagram Inner Model

From figure 3 and table 6 above shows that the five direct effect of three models between exogenous variables with endogenous variables, is indicated that not all path coefficients 
significant at 5\% error rate. In Model 1, the line between the roles of government influence (X) on the Role of CWS (Y1) has a path coefficient of 0.548 with a p-value of 0.001 . Government's role variable (X) has significant impact on the role of CWS (Y1). Government's Role variable (X) gives a positive and significant effect on the Role of CWS (Y1). It means that more important the role of government, more positive direct impact to the role of CWS.

In Model 2, the line between the role of government influence (X) on the role of Private (Y2) is indicated that the Government's role of variable $(\mathrm{X})$ has a path coefficient of 0.304 with a pvalue of 0.025 . Government's role variable $(X)$ gives a positive and significant effect on the Role of Private (Y2). The better the role of government, the better direct positive impact on the private sector's role. In Model 2, the line between the role of government influence (X), role CWS and role of Private (Y2) of the Restoration of Mangrove (Y3), It is indicated that the Government's role variable (X) has a path coefficient of 0191 with a p-value of 0151 . P-value is more than 0.05 that is indicates that the variable Role of Government (X) does not provide significant direct influence on mangrove restoration (Y). Variable role of CWS (Y1) has a path coefficient of 0.424 with a p-value of 0.002 . P-value less than 0.05 is indicated that the variable role of CWS gives positive and significant direct effect on mangrove restoration (Y). Private role variable (Y2) has a path coefficient of 0439 with a p-value of 0.002 . P-value is less than 0.05 that is indicated that the variable role of private gives positive and significant direct effect on mangrove restoration (Y). Private Role influence lines (Y2) of the Restoration of Mangrove (Y3) has the highest coefficient. This indicates that the most dominant influence directly shown by the private sector's role (Y2).

\section{RESULTS AND DISCUSSION}

In terms of testing indirect influence government variable (X) is related to rehabilitate mangrove (Y3) via a variable role of CWS (Y1) and the role of the private sector (Y2) as mediation. Testing the effect of mediation variables is done only if there is a direct effect which significant between predictor variables and the response variable, but there is a chance conceptually that there is a mediation variable between these two variables (Bennett, 2000).

Table 5: The results of testing the effect of mediation role CWS (Y1) and the role of the private sector (Y2)

\begin{tabular}{lllll}
\hline $\begin{array}{l}\text { Exogenous } \\
\text { variable }\end{array}$ & $\begin{array}{l}\text { Mediation } \\
\text { variable }\end{array}$ & Endogen variable & $\begin{array}{l}\text { Indirect } \\
\text { influence }\end{array}$ & P-value \\
\hline Government & CWS role(Y1) & Mangrove & 0.233 & $0.023^{* *}$ \\
role (X) & Private role (Y1) & restoration (Y3) & 0.134 & $0.066^{*}$ \\
\hline
\end{tabular}

\section{Remarks :}

** : Significant at the 5\% error level

* : Significant at the $10 \%$ error level

Indirect influence variable of Government role (X) of the restoration of mangrove (Y3) through private role (Y2) as mediation is equal to 0.134 and p-value of 0066 . P-value is less than 0.10 . That it is indicated that the indirect effect is formed significantly in $10 \%$ error level. Therefore, it is proved from testing with test that the variable of private role (Y2) is link to mediation variable linking of government role (X) of the mangrove Restoration (Y3). Indirect influence of variable government role (X) of the Restoration of Mangrove (Y3) through CWS role (Y1) is higher than through the private role (Y2). It concludes that to improve Mangrove restoration, the government encourages CWS more than encourage the private sector. 
The formulation of strategies for dealing with mangrove restoration in the village of mangunhardjo in this study used SWOT analysis. SWOT analysis is the identification of various factors systematically to formulate strategy. This analysis is based on the logic that maximize strengths and opportunities, but at the same time can minimize weaknesses and threats (Rangkuti, 2001).

There are many factors to be opportunities, threats, strengths and weaknesses of the process of handling the mangrove restoration in Mayangan.

Table 6.Factors of SWOT

\begin{tabular}{|c|c|c|c|c|c|c|}
\hline & Strength & \multicolumn{2}{|r|}{ Weakness } & Opportunity & \multicolumn{2}{|r|}{ Threats } \\
\hline 1. & Availability of & 1. & Lack & 1. easily & 1. & Corruption in \\
\hline & funds for & & transparency & cooperative & & bureaucracy \\
\hline & restoration & & of budget; & society; & 2. & overlapping \\
\hline 2. & Excellent CWS & 2. & Lack & 2. active role of & & authority \\
\hline & Performance & & coordination & community & 3. & restoration \\
\hline 3. & CSR fund & & among & 3. Social culture & & mangrove \\
\hline & from private & & & change & & project \\
\hline & sector & & private and & & & delayed \\
\hline & Rules and & & local people; & & & because \\
\hline & regulation & 3. & Lack & & & bureaucracy \\
\hline & & & community & & & factors \\
\hline & & & awareness & & 4. & Illegal mangrove \\
\hline & & 4 & I ack of human & & & logging \\
\hline & & & Lack OI MUMIIII & & & \\
\hline & & & resources & & & \\
\hline & & 5. & governments is & & & \\
\hline & & & less serious in & & & \\
\hline & & & mangrove & & & \\
\hline & & & restoration & & & \\
\hline & & & program & & & \\
\hline
\end{tabular}

To formulate strategy for mangrove restoration, it is rely on PLS analysis both internal and external environment that it has been stated in structural model as shown in figure 3. Analysis of the internal environment can be applied using IFAS analysis. From the analysis using IFAS matrix, it can be calculated weights, ratings and scores to determine the priority situation. By using the IFAS matrix scores, it will get that superior strength and greatest weakness should be solved. Analysis of the external environment can be applied using EFAS analysis. From the analysis using EFAS matrix, it can be calculated weights, ratings and scores to determine the priority situation. By using the matrix scores EFAS, it will get the greatest opportunities that can be applied and the biggest threat should be avoided. 
Table7: IFAS Matrix

\begin{tabular}{|c|c|c|c|}
\hline Internal Strategy Factors & Wegiht & Rating & Score \\
\hline \multicolumn{4}{|l|}{ Strength } \\
\hline 1. Availability of funds for rahabilitation & 0.11 & 3 & 0.33 \\
\hline 2. Exellence CWS performance & 0.18 & 4 & 0.71 \\
\hline 3. CSR fund from private sector & 0.07 & 3 & 0.20 \\
\hline 4. Rules and Regulation & 0.20 & 4 & 0.80 \\
\hline \multicolumn{4}{|l|}{ Weakness: } \\
\hline 1. Lack of budget transparency & 0.13 & 4 & 0.53 \\
\hline $\begin{array}{l}\text { 2. Lack of coordination among government, private } \\
\text { and local people }\end{array}$ & 0.04 & 4 & 0.18 \\
\hline 3. Lack of community awareness & 0.09 & 1 & 0.09 \\
\hline 4. Lack of human resources & 0.02 & 3 & 0.07 \\
\hline \multirow{2}{*}{ 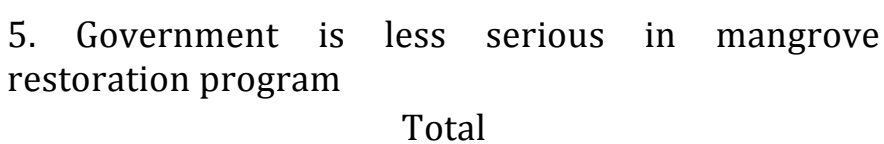 } & 0.16 & 4 & 0.62 \\
\hline & 1.00 & & 3.53 \\
\hline
\end{tabular}

Based on Table 7 above, it can be explained that the highest scores of IFAS matrix is the rules and regulations which is equal to 0.80 . This suggests that in dealing with mangrove restoration, rules and regulations are clearly a driving force. Both legal sanctions law and customary regulation is a key force in the process of mangrove restoration the village of Mayangan. In addition, CWS performance has the second highest score. It means that the government helps the CWS indirectly in overseeing the mangrove forest. Thus, CWS act as an agent of the government to the public. In addition, the role of direct CWS may be able to accommodate the community hope to participate in the process of restoration of mangrove forests.

Table 8: EFAS Matrix

\begin{tabular}{lccc}
\hline \multicolumn{1}{c}{ External Strategy Factors } & Weight & Rating & Score \\
\hline Opportunity: & & & \\
1. Easily cooperative society & 0.14 & 4 & 0.56 \\
2. Active role of community & 0.18 & 4 & 0.72 \\
$\begin{array}{l}\text { 3. Social culture change } \\
\text { Threats: }\end{array}$ & 0.04 & 2 & 0.08 \\
$\begin{array}{l}\text { 1. Corruption in bureaucracy } \\
\text { 2. Overlapping authority }\end{array}$ & 0.25 & 4 & 1.00 \\
$\begin{array}{l}\text { 3. Restoration mangrove project is delayed } \\
\quad \text { because of bureaucracy factors }\end{array}$ & 0.11 & 2 & 0.22 \\
4. Illegal mangrove logging & 0.07 & 3 & 0.21 \\
Total & 0.21 & 4 & 0.84 \\
\hline
\end{tabular}

Based on the analysis of EFAS matrix, it can be seen that the external factor score is 3.63. matrix, it can be seen that the external factor score is 3.63 . 


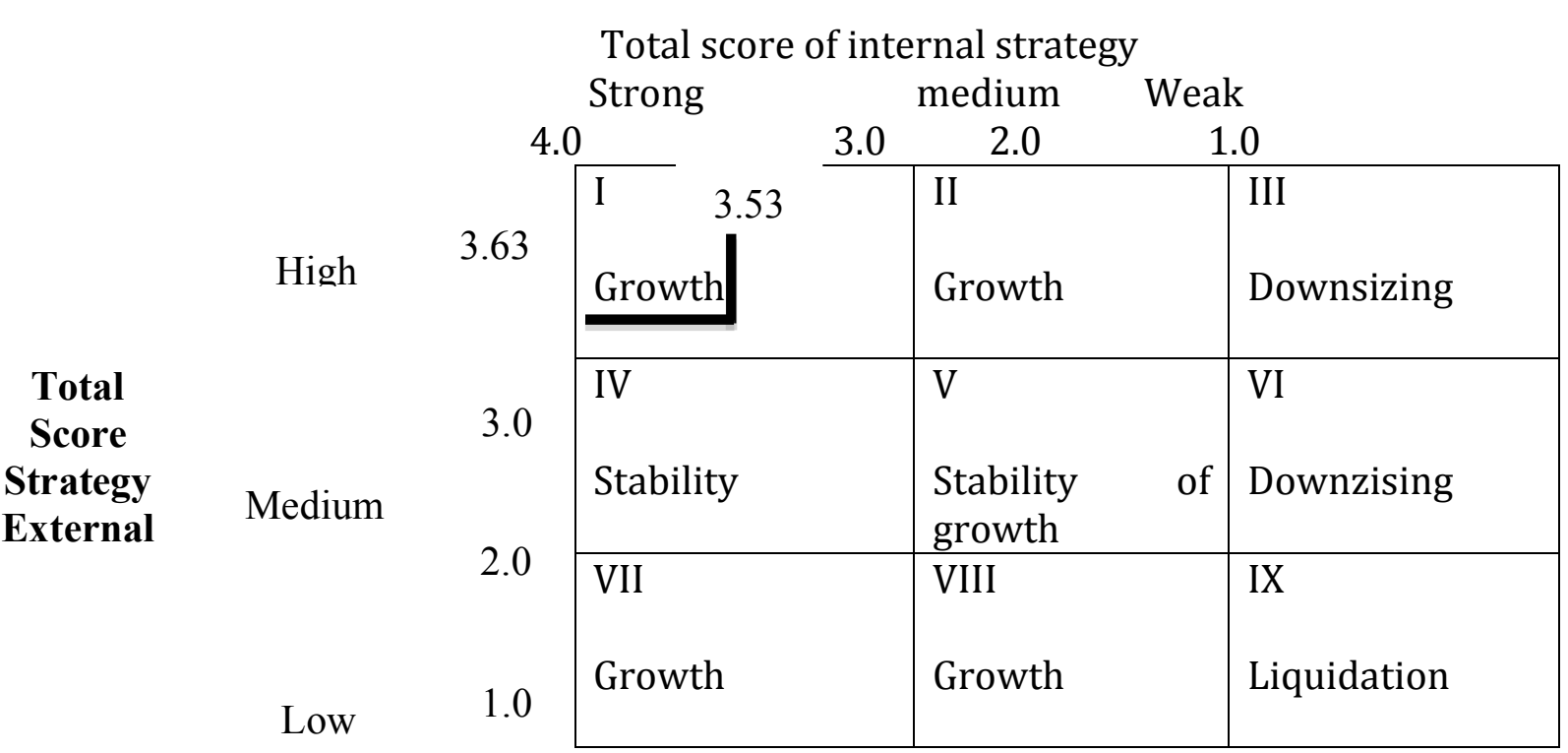

Figure: 4 Internal-External Matrix to restore mangrove in Mayangan

As explained in the analysis of IFAS matrix that it has score 3.53. While, score of EFAS matrix is equal to 3.63. Both scores are implementing to the matrix of IE. Based on the matrix Internal External above, it can be seen that the strategy according to the position of "Growth". Growth is horizontal integration strategy by expanding into a larger area. This strategy can be applied in the presence of a more thorough dissemination to the public. In addition, the growth strategy through vertical integration can also be done in the bureaucracy. For example, it needs closer scrutiny in the process of handling mangrove restoration.

Table 11: SWOT Matrix

\begin{tabular}{|c|c|c|}
\hline EFAS & $\begin{array}{ll}\text { Strenghts (S) } \\
\text { 1. Available of funds for } \\
\text { restoration } \\
\text { 2. Excellence CWS performance } \\
\text { 3. CSR fund from private sector } \\
\text { 4. Rules and regulation }\end{array}$ & $\begin{array}{l}\text { Weakness (W) } \\
\text { 1. Lack of transparency of budget } \\
\text { 2. Lack of coordination among } \\
\text { government, private and local } \\
\text { people } \\
\text { 3. Lack of community awareness } \\
\text { 4. Lack of human resources } \\
\text { 5. Government is less serious in } \\
\text { mangrove restoration program }\end{array}$ \\
\hline $\begin{array}{l}\text { Opportunities }(\mathbf{O}) \\
\text { 1. Easily cooperative sociiety } \\
\text { 2. Active role of community } \\
\text { 3. Social and culture change }\end{array}$ & $\begin{array}{l}\text { Strategy SO } \\
\text { 1. Increase the dissemination to the } \\
\text { public. } \\
\text { 2. CWS given authority to run the } \\
\text { mangrove restoration program. } \\
\text { 3. CWS given the authority to } \\
\text { oversee the mangrove forest. } \\
\text { 4. Budget planning, especially for } \\
\text { mangrove restoration involve the } \\
\text { community. }\end{array}$ & $\begin{array}{l}\text { Strategy WO } \\
\text { 1. Current Reports on the activities } \\
\text { and financial restoration of } \\
\text { mangrove opened to the public. } \\
\text { 2. People are asked to participate in } \\
\text { monitoring government } \\
\text { performance, especially in } \\
\text { mangrove restoration. } \\
\text { 3. Establish a more intense } \\
\text { communication between } \\
\text { government, private, and } \\
\text { community. } \\
\text { 4. Improving the quality of human } \\
\text { resources. }\end{array}$ \\
\hline $\begin{array}{l}\text { Threats (T) } \\
\text { 1. Corruption in bureaucracy } \\
\text { 2. Overlapping authority } \\
\text { 3. restoration mangrove project is } \\
\text { delayed because of bureaucracy } \\
\text { factors } \\
\text { 4. Illegal logging of mangrove }\end{array}$ & $\begin{array}{l}\text { Strategy ST } \\
\text { 1. Formulated clear rules and } \\
\text { regulations concerning the rights } \\
\text { and obligations, duties, and } \\
\text { penalties for noncompliance. } \\
\text { 2. Involve the community especially } \\
\text { CWS in performance monitoring. } \\
\text { 3. The application of customary law } \\
\text { in accordance with the collective } \\
\text { agreement. }\end{array}$ & $\begin{array}{l}\text { Strategy WT } \\
\text { 1. capitalize Pokmaswas to prevent } \\
\text { illegal logging. } \\
\text { 2. The Government shall coordinate } \\
\text { with the community to promote } \\
\text { mangrove planting program. } \\
\text { 3. The application of a more serious } \\
\text { legal sanctions both legal } \\
\text { regulations and customary law. }\end{array}$ \\
\hline
\end{tabular}


Based on the SWOT matrix above, it could be Formulated strategy as follows:

\section{Strength-Opportunity Strategy}

Based on the strategy established in the SWOT matrix, SO strategy includes:

1. Increase the dissemination to the public.

2. CWS is given authority to run the mangrove restoration program.

3. CWS is given the authority to oversee the mangrove forest daily.

4. Budget planning, especially for mangrove restoration should involve the community.

\section{I1. Weakness-Opportunity Strategy}

Strategy is composed of the following:

1. Current Reports on the activities and financial restoration of mangrove opened to the public.

2. People should participate in monitoring government performance, especially in mangrove restoration.

3. Establish a more intense communication between government, private, and community.

4. Improving the quality of human resources.

\section{Strategy Strength-Threats}

Strategy is composed of the following:

1. Local government should prepare rules and regulations concerning the rights and obligations, duties, and penalties for noncompliance.

2. Involve the community especially CWS in performance monitoring.

3. The application of customary law in accordance with the collective agreement.

\section{Strategy Weakness-Threats}

Strategy composed of the following:

1. Capitalize CWS to prevent illegal logging.

2. The Government shall coordinate with the community to promote mangrove planting program.

3. The application of legal sanctions over seriuts both statutory law and customary law.

\section{CONCLUSION}

The role of CWS to participate in mangrove restoration in the coastal area is extremely important. The local government should give more authority and delegate to CWS to plan and to execute as well as to monitor mangrove growth. The existing condition CWS in doing monitoring of mangrove is just relying on the assistance from local government and they could not stand alone. CWS has strong motivation and courage to restore mangrove with their own cost. Unfortunately, their limited budget could not do much. Sometimes, local government contribute with thousands of seed mangrove, but in the maintenance stage, there is no budget for operation and maintenance. Therefore, there is opportunity to restore damaged mangrove even to expand for other lands. the key to success for coastal restoration is a partnership among the community and the government as well as with the private sector. thus, strengthening institutional CWS become an important requirement. They include strengthening human resources through various training and education, financial assistance on a regular basis for operations, preparation of program planning, mangrove planting and monitoring as well as reporting

\section{ACKNOWLEDGMENTS}

The author is gratefully to thank to Dean of Faculty of Marine Science of Brawijaya University - Professor Dr. Ir Diana Afiarti, MS to give me a chance to conduct research in the framework between biology science and policy framework. 


\section{References}

Affan, J. M. 2010. Potential Analysis of Marine Resources and Water Quality Parameters Based Physics and Chemistry at the East Coast Central Bangka . Volume 10 Number 2

Anwar , J. , Hisham , N. And Damanik , S.J. 1984. Ecosystem Ecology Mangrove.UGM Press . Yogyakarta

Bengen D.G. 2000. Synopsis Coastal Ecosystems and Natural Resources . Research Center of Coastal and Marine Resources . Bogor Agricultural Institute. Bogor, Indonesia

Boyd, C.E., 1988. Water Quality Management For Pond Fish Cultur. Developments In Aquaculture And Fisheries Science, Volume 9. Auburn University

Fauzi, Akhmad. 2010. Fisheries economic: theory, policy and Management. PT. Gramedia Pustaka Utama, Jakarta

Ghozali , 1 . 2008. Structural Equation Modeling : Alternative Methods with the " Partial least squares " . Agency publisher of Diponegoro University . Semarang

Djohan, T.S., 2010. Dinamika Kualitas Plankton Diperairan Ekosistem Hutan Bakau Segara Anakan Yang Sedang Berubah. Jurnal Manusia Dan Lingkungan.

Haryanto , 2008. Rehabilitation of Mangrove Forests : Ecosystems Coastal Conservation and Coastal Community Empowerment. STAIN Pamekasan

Hutching, P and P.Saenger, 1987. Ecology of Mangroves. University of Queensland, London.

Kathiresan, K. and B. L.Bingham.2001. Methods of studying Mangroves. Marine Biology Annamalai University

Kusmana , C. , 2009. Integrated Management of Mangrove Systems . Faculty of Forestry , Bogor Workshop on Mangrove Ecosystem Management in West Java

Mukhtasor . 2007. Coastal and Marine Pollution . Jakarta : Pradnya Paramita . 322 hal .

Noor , Y.R , M Khazali and I.N.N Suryadiputra.1999 . Guide the introduction of mangrove in Indonesia.Bogor

Onrizal . 2002. Evaluation of Damage Zone And Alternative Mangrove rehabilitation in West Java and Banten . University of North Sumatra

Rudianto. 2014. Restoring Coastal Ecosystems-a case study Malang and Gresik regency, Indonesia. Journal of Coastal Conservation Planning and Management, ISSN 1400-0350. Volume 18.

Sodikin , 2013. Mangrove destruction And Correlation Of Seawater Intrusion Levels (A Case Study in the village of Muara Beach Happy Kingpin Bekasi Regency ) . Thesis . Master Program in Environmental Science Graduate Program Dionegoro University of Semarang

Rahayu , Sri . 2014. Characteristics of Environmental Quality Mangrove Rehabilitation In Region Mangunharjo Village , District Mayangan , City of Probolinggo , East Java . Thesis . Faculty of Fisheries and Marine Sciences . UB

Wibowo , 2009. Legal and Institutional Aspects in Increasing the Efficiency and Effectiveness of Coastal Management . Journal of Law No. 1, the volume of January 16, 2009

Wiyono , M. 2009. Management of Mangrove Forest and its appeal as attractions in Probolinggo City . Malang State University. 